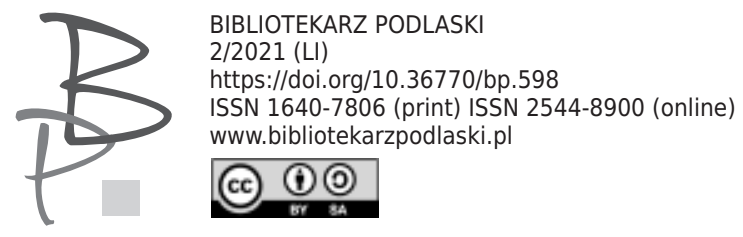

Joel J. Janicki*

Soochow University, Taipei, Taiwan / Uniwersytet w Soochow, Tajpej, Tajwan

\title{
Coercion and Coerciveness in the Politics of Cold-War Ukraine and Taiwan
}

Abstract: The present study is devoted to an examination of the prison memoirs by the Ukrainian writer, Mykhaylo Osadchy (1936-1994) and the Taiwanese writer Tsai Tehpen (b. 1925) from the perspective of coercion. Osadchy was a member of the Sixtiers, a group of young Ukrainian intellectuals who brought about cultural renaissance in post-Stalin Ukraine. Their writings marked a strong reaction against Moscow's policy of great-power chauvinism at the onset of the regime change that marked the end of Khrushchev's liberalizing campaign. Osadchy was one of the victims of the subsequent wave of arrests of dissidents in the Soviet Union, including Ukraine, in 1965. His memoir, Cataract (1971) is a powerfully evocative response to trumped-up charges of subversion, anti-Soviet agitation and bourgeois nationalism, and a riveting description of life in a Mordovian labor camp, a work that posed a strong attack on official Soviet culture.

Key words: Ukraine, Taiwan, Prison Memoirs, coercion, Authoritarianism.

* Joel J. Janicki - dr, literaturoznawca; pracuje na Uniwersytecie w Soochow (Tajpej, Tajwan); autor licznych artykułów, m.in. "Father Complex and Parricide in Andrei Bely's Petersburg", "Integrams", No. 16.1 (2015). 
"...human thought is sometimes bent out of shape by the pressure of political interests, a phenomenon commonly known as ideology". Terry Eagleton "A wszystko co się dzieje u nas to niezakończone". Jurij Andruchowycz

The present study uses the genre of prison memoir to investigate the response of the Taiwanese and Ukrainians to the coercive politics of government authorities in their respective countries in the Cold War period. The numerous victims of the Cold War ideology of confrontation and battling the enemy starkly shaped the realities of the existence in post-World-War-II Ukraine and Taiwan. Though Western historians tend to see the origin of the Cold War as stemming from Stalinist policies in Europe and abroad, US ambitions to secure access to global markets and contain the spread of communism was the stated strategic policy of Harry Truman, "a policy of calculated and gradual coercion"1 and therefore a policy of its allies in Europe and Asia.

\section{Tsai Tehpen and Elegy for Sweet Potatoes}

The two prison memoirs are Tsai Tehpen's Elegy for Sweet Potatoes (1995), and Mykhaylo Osadchy's Cataract (Bil'mo 1971). Tsai's fictionalized memoir is a description of the thirteen-month period (Oct, 1954-Nov, 1955) that began with the author's arrest, interrogation and imprisonment when he, a member of the ruling Kuomindang (KMT), was caught up in the extensive network of the White Terror campaign in Taiwan. It is a description of his relationship with state agents and police investigators and his efforts to extricate himself from

1 J. Steele, "Who started it?" (Review of The Cold War: A World History by Odd Arne Westad), "London Review of Books" 2018, January 25, p. 23. 
the tangled web of deceit and denunciations characteristic of a police state. It is also a tribute to his fellow Taiwanese victimized by the KMT regime, whose stories Tsai relates. His "not-guilty verdict" and release after only thirteen months in prison point to a change in an official policy toward arrestees by the mid-150s. The suspension of the mandatory torture of prisoners and obtaining confessions under duress was a reflection of a growing sense of stability of the regime at that time, of the ebbing of fears of a Mainland invasion and takeover of the island, and of the effectiveness of the financial and military support provided by the United States. Tsai, therefore, was fortunate in avoiding the brunt of coercive measures inflicted on political prisoners arrested just a few years earlier in the none-too-discriminating net of the political police ${ }^{2}$.

The nature of traditional Taiwanese society is that of a collectivity based on social networks, a society characterized by an embedded kinship including economic and business ties. With the arrival of the mainlanders beginning in 1947 and their takeover as the ruling class, the waisheng (Chinese-born), of Taiwan became predominant and overrepresented in government agencies and government-owned, mostly large-scale industries. "A culture of psychosis" ensued marking by a sense of exclusion of the native Taiwanese ${ }^{3}$.

In the aftermath of the regime change in post-war Taiwan, 36,000 Taiwanese were forced out of government positions they had occupied during the Japanese colonial period (1895-1945). Their ethnic identity led to unfair treatment and posed a barrier to social advancement; this resulted in a split in the typically unified mindset of citizenship and nationality. Taiwan was essentially regarded as a base for the KMT's ongoing effort to launch a successful invasion of China, a means to an end ${ }^{4}$.

Tsai Youde, the narrator of the memoir and personification of the author Tsai Tehpen, was born on Dec 6, 1925 in Putzu in Chia-yi County in south-

2 According to Article 7 of the Sedition Law, any form of communication or description of the doings of the government's security organs and military against their own people would be interpreted as "engaging in behavior beneficial to the enemy." The policy of torturing prisoners during interrogation was amended by the time Tsai was imprisoned, as too many prisoners had been tortured to death; torture was henceforth allowed only with solid evidence of the prisoner's "guilt". T. Tsai, Elegy of Sweet Potatoes: Stories of Taiwan's White Terror, Transl. G. Hatch, Taipei 1995, p. 482.

3 J. Taylor, The Generalissimo's Son: Chiang Ching-kuo and the Revolutions in China and Taiwan, Cambridge 2000, p. 146.

4 Ibidem, p. 148. 
central Taiwan. An enterprising student, he formed the Drama Society and Student Friendship Association at the recently founded Taiwan Normal University in 1948. His idealistic purpose in founding the organization was to promote the revitalization of the Taiwanese language which had been banned in the second half of the Japanese occupation under its Japanization Policy. The language continued to be suppressed during the National Language Advancement Program of the KMT. At the same time, disenchantment with the corruption of the Nationalist Government led to the 228 Incident (1947) and subsequent government crackdowns. By 1949 students had come to view corruption as one of the major factors in the KMT's defeat in the civil war on the Mainland, extending their sympathy for the communists and communism. Youde's drama club in particular attracted progressive reform-minded students, some of whom were members of the Communist Party. One of the plays put on by Youde, Tsao $Y u$-The Sun's Rise-was a Taiwanese-language performance of a Mainland proletarian drama. The Student Friendship Society established by Youde attracted a number of students with communist leanings. Nearly all of these students were arrested in the April 6 crackdown. Youde's affiliation with this group would lead to his eventual arrest in 1954.

\section{Mykhaylo Osadchy and Cataract}

Mykhaylo Osadchy (1936-1994), a child of the Soviet state, grew up in western Ukraine, and developed his writing skills as a student of journalism at Lviv University and as a poet with a debut volume entitled $A$ Moonlit Field (1965). Prior to his arrest in 1965, he had worked for a Lviv television studio and was a lecturer in Journalism at Lviv University. He was a member of the Communist Party and a member of the state-run Union of Journalists. As a dutiful Soviet citizen, he lectured on the duties of the Soviet press, and supported ideological education. Academically and professionally active, he wrote a thesis devoted to the Ukrainian satirical writer Ostap Vyshnya (1889-156), a victim of repression in Stalinist times.

Osadchy was a member of the Sixtiers, a generation of Ukrainian writers and intellectuals who flourished in the relatively open Soviet society fostered by the policies of Nikita Khrushchev in the late 1950s and early 1960s. This 
period of openness lasted until a crackdown was imposed at the onset of the new conservative regime under Leonid Brezhnev in 1965, the year of Osadchy's arrest. Khrushchev's tendency in the post-Stalin years was to eschew coercion and use persuasion in dealing with social issues, while highlighting efficiency and managerial skills. By opening up travel opportunities, toning down russification, relaxing ideological constraints, and removing much of the fear and stifling conformity of Stalin's regime, he helped to bring about a freer atmosphere that encouraged creative expression ${ }^{5}$. The early sixties was a time when Ukrainian writers felt empowered to address "the sorry state of the Ukrainian language" - a forgotten language during the height of Stalinism when writers were forced to yield to the dominance given to Russian in official discourse. Students and young writers protested against the marginalization of the language and the "provincialization" of Ukraine in its abject observance of party guidelines. Beginning in the late 1950s, Ukrainian was given much freer rein at the university with the establishment of Ukrainian language journals, such as Ukrainskyi Istorychnyi Zhurnal. Among the Sixtiers, it also marked a rediscovery of their cultural heroes of the recent past with the rehabilitation of such major writers as Mykola Skrypnyk ${ }^{6}$ (1872-1933), Mykola Khvylovy (1893-1933), Mykola Kulish (1892-1937) and Mykhailo Drahomanov (1841-1895)

The immediate post-Stalin years witnessed a growth spurt of the Ukraine Communist Party. Membership expanded rapidly, drawing upon idealistic youth from the entire nation, not just the traditional communist stronghold of the industrialized east. The confidence and self-importance exuded by the young elite together with reduced levels of fear that had permeated society from the 1930s until Stalin's death, led to a revival of Leninism with its liberal view of the cultural and political autonomy of Soviet nationalities and open 2013, p. 13.

5 R. Hornsby, Protest, Reform and Repression in Khrushchev's Soviet Union, Cambridge

6 Skrypnyk was a proponent of Ukrainian independence and a leading figure in the Ukrainian cultural movement in Soviet Ukraine in the 1920s, and chose to commit suicide rather than recant his pro-Ukrainian views at a show trial in 1933. In the same year Khylovy also committed suicide as a form of protest against Soviet repression of Ukrainian cultural autonomy. Kulish was arrested by the NKVD in 1934 and was one of over two hundred Ukrainian exiles executed at Sandarmoch (Karelia) in 1937.

7 O. Subtelny, Ukraine: A History, Fourth Edition, Toronto 2009, p. 502. 
expressions of their skepticism towards the authoritarian regime and against the limits on liberalization it imposed.

A wave of arrests over Ukraine marked the end of Khrushchev's liberalizing campaign. Hundreds of Ukrainian dissidents were swept up, their writings confiscated. Osadchy was one of the victims of the tightening of official controls highlighted by the arrest of Andrei Sinyavsky and Yuliy Daniel ${ }^{8}$ in September, 1965 and their subsequent high-profile trial. Osadchy was arrested somewhat earlier in August, 1965. Osadchy was tried for subversion, anti-Soviet agitation and bourgeois nationalism. He then waited for a court decision for eight months, which resulted in a prison term of two years. After the appearance of his prison memoir, Cataract, in West Germany, he was rearrested in 1972, sentenced to further seven years of prison and three years in exile. His first stay in prison in a labor complex in Mordovia, a region west of the Volga River, was the primary setting of his memoir.

Cataract, written in between the two prison terms and the primary reason for Osadchy's second arrest, is a representative product of Samodav (Samizdat) literature - Soviet uncensored writing. The memoir was first published abroad in 1971 with the English language version published in 1976. It is a highly evocative account of his own plight, his trial and imprisonment and the fate of his fellow inmates, marked by a rich and at times highly imaginative and poeticized language. It is stylistically impressive, riddled with political obscenities that mark the back and forth exchanges he held with fellow dissident writers, guards, wardens, and KGB interrogators. Cataract in its expressiveness and emotionalism of descriptions has been compared to painterly experiments by artists from Kiev and Lviv in the early 1960s, including Ivan Marchuk's (b. 1936) The Sad Raven ${ }^{9}$.

8 The trial was conducted against the writers Andrei Sinyavsky and Yuli Daniel in Moscow in February 1966 after their arrest in September 1965, a timeline similar to that of Osadchy. The Russian writers were convicted of anti-Soviet agitation and propaganda for publishing their satirical writings abroad, as was the case with the publication of Osadchy's Cataract in Western Europe in 1972. They were sentenced to seven and five years in a strict-regime labor camp, respectively. Osadchy's second imprisonment was for seven years in a strict-regime camp. According to Lyudmila Alexeyeva, their trial was the first Soviet show trial of writers being convicted solely for their literary work. The trial generated harsh criticism from official Soviet media and became a cause celébré among émigré intellectuals and sympathizers in the West. L. Alexeyeva, P. Goldberg, The Thaw Generation: Coming of Age in the Post-Stalin era, Pittsburgh: 1990.

9 M. Carynnyk, "Caliban's Education”" (Translator's Introduction), [in:] M. Osadchy, Cataract, transl., edited and annotated by M. Carynnyk, New York 1976, p. 8. 
The tremendous pressures a writer/prisoner of conscience undergoes in prison renders the intellect and emotions even more acute, especially those of a writer endowed with poetic expressiveness, "a poet of the Ukrainian resistance" imprisoned for independent thinking. Osadchy renders transparent his organic poetic process by his evocative imagery: a fallen leaf in sorrow, day turning into night, one heart touching another reflects the suffering of a spiritually free individual behind bars. The mood is often grim; the prison experience deprives him of natural human emotions that give rein to an unrestrained expressiveness that is a response to his condition. The incarceration compels him to rely on his inner resources, even as he develops a closer relationship to Ukraine and Ukrainians, and takes on a search for and discovery of spiritual forefathers, such as Dante and Shevchenko, poets who themselves had suffered at the hands of political authorities. The long years of resisting coercive measures and the suffering brought about by prison and exile allowed him to enter the promised land of spiritual salvation.

\section{Coercion and Coerciveness}

Coercion is typically thought to carry with it several important implications, including the fact that it diminishes the targeted agent's freedom and responsibility, and that it is a wrong imposed on an individual and/or a violation of his rights. A state's legitimacy and sovereignty are sometimes thought to depend on its ability to use coercion effectively and to monopolize its use within its territory against competitors, and in the present case, dissidents and critics of the state, both internal and external ${ }^{10}$.

Coercion, in one sense, can be seen as a state response to social unrest, non-violent resistance as well as acts of terrorism, and is associated with the concomitant infringements of individual rights by the state/state agents. It is frequently associated with such terms as violence, punishment, compulsion, force and interference. According to the Stanford Encyclopedia of Philosophy, "coercion has commonly been understood as the use of a certain kind of power for the purpose of gaining advantages over others (including self-protection),

10 Coercion, [in:] Stanford Encyclopedia of Philosophy, Revised version, 2011. 
punishing non-compliance with demands, and imposing one's will on the will of other agents"11. The use of coercion by the authoritarian state to maintain its position of unchallenged authority becomes cannibalistic, however, when it uses its overpowering resources to stifle the perceived dissent by detaining individuals was deemed harmful to the status quo, subjecting them to inhumane treatment, sentencing them either to death or to inordinately long prison terms, and thereby intimidating society as a whole from exercising their human rights and speaking and acting in accord with their conscience.

The actions of the victim of coercion (coercé/e), his/her blameworthiness and the justification of coercion from the point of view of the state are a subject of great interest. Coercion includes in its potent arsenal the threat of violence that intimidates, and thereby prevents action. The irreparable harm done to individuals and society by violent acts of coercion is addressed in numerous prison memoirs in addition to the two herein examined.

Among noteworthy thinkers who considered the notion of coercion is Thomas Hobbes (1588-1669), author of Leviathan (1650). Written in the perilous years of the English Civil War, Hobbes expressed his concerns about external threats to the viability of the state. In doing so, he examined the nature of coercion and its role in the function of justice and of the state, seeing it as a necessary part of a state's function. He described the obligations the state/ subject contract imposes on both parties and in the event of violations of the contractual agreement perpetrated by the subject, and affirmed the state's right to use coercion going back to the Constitution of that state ${ }^{12}$.

John Locke's (1632-1704) expressed concern was of the very nature of an autocrat who is liable to become a potent tyrant due to his ability to marshal security forces and organize armies. Locke, whose Treatise of Two Governments (1689) was also written during a tumultuous period of the civil war in the 1680 s, which culminated in the Glorious Revolution, focused on the rightness of the sovereign's use of power together with the right of the individual to challenge the sovereign's right to rule when the latter goes beyond the laws'

11 Ibidem, p. 1.1.

12 Th. Hobbes, Leviathan. Ed. Noel Malcom. Oxford: Clarendon. See also: S. A. Lloyd, S. Sreedhar, Hobbes' Moral and Political Philosophy, [in:] Stanford Encyclopedia of Philosophy, 2012. 
stipulations: "wherever the law ends, tyranny (coercion) begins." 13 The authority of the sovereign rests in the consent of the governed to preserve stability and to prevent, among other things, a rebellion among the governed.

Immanuel Kant (1724-1804) is a sublime representative of the Enlightenment thought who placed emphasis on reason and autonomy rather than dependence on authority. He viewed coercion as a tool to control the lawless to respect the rights of others and to control the behavior of those who are not self-governed by a sense of duty ${ }^{14}$. John Stuart Mill (1806-1873), meanwhile, thought more in social than political terms, and was a champion of individual rights. He stated that the state was not entitled to regulate people's behavior for their own good, though it is entitled to punish lawbreakers. In On Liberty (1859), Mill expressed a more expansive view of what coercion is and its implications for personal liberty.

With the ominous rise of totalitarian states, $20^{\text {th }}$-century views of coercion tended to center around the use of force to compel conformity or the threat to use such force. Hans Kelsen (1934) characterized coercion as the state's identification of individuals who were deemed as its potential enemies and the subsequent detaining of them indefinitely in internment camps without due process $^{15}$.

J. R. Lucas (1929) was concerned with the bloody-mindedness of the use of force in spite of the individual's efforts to counteract such use: "A man is being coerced when either force is being used against him or his behavior is

13 "Where-ever law ends, tyranny begins, if the law be transgressed to another's harm; and whosoever in authority exceeds the power given him by the law, and makes use of the force he has under his command, to compass that upon the subject, which the law allows not, ceases in that to be a magistrate; and, acting without authority, may be opposed, as any other man, who by force invades the right of another. This is acknowledged in subordinate magistrates. He that hath authority to seize my person in the street, may be opposed as a thief and a robber, if he endeavors to break into my house to execute a writ, notwithstanding that I know he has such a warrant, and such a legal authority, as will empower him to arrest me abroad. And why this should not hold in the highest, as well as in the most inferior magistrate, I would gladly be informed. "Of Tyranny" in Two Treatises of Government, Book II, Chapter XVIII, Section 202.

14 M. Rohlf, Immanuel Kant, [in:] The Stanford Encyclopedia of Philosophy (Summer 2018 Edition), ed. Edward N. Zalta, URL = https://plato.stanford.edu/archives/sum2018/entries/ kant/

15 The Pure Theory of Law, trans. M. Knight (Los Angeles: University of California Press, 1967), original German first edition 1934; second edition, 1960, 34. 
being determined by the threat of force" 16 and "...imprisonment is the paradigm form of coercion". The state is guilty of abuse in the event of rendering the individual helpless to resist a judgment being implemented against him ${ }^{17}$.

The most fundamental contemporary account of coercion is Robert Nozick's essay Coercion (1972). Nozick (1938-2002) makes use of logical language by associating coercion with proposals (e.g., conditional threats), but excludes the direct use of force or violence. His view asserts that "coercion takes place only when the coercee acquiesces to it"; thus, "it makes coercion explicitly dependent on the coercee's choice to take or not take a specific action, and mandates that a judgment about coercion must refer to facts about the coercee's psychology, such as his/her assessment of the consequences pertaining to the designated action in light of the coercer's proposal. The overall effect of these differences is to focus the analysis of coercion on how the coercee reacts to it and is affected by it, rather than on what the coercer does, and what is required for him or her to do it successfully.

Nozick limits his discussion of coercion to techniques that influence or alter the will of the coercee, by altering the intentions or dispositions of the coercee. Such coercion usually takes the form of a conditional threat (or sometimes a conditional offer). At the same time, a distinction is made between the notion of coercion and coerciveness. It is essential to examine the specific events in the life of a coercee to determine those that alter or constrain his activities allowing one to distinguish coercion from coerciveness, associating the former with completed, successful attempts, and the latter with qualities of the attempt itself ${ }^{18}$.

The following discussion makes use of Nozick's understanding of coercion to examine several features of the two prison memoirs described above ${ }^{19}$.

16 J. R. Lucas, The Principles of Politics, Oxford 1966, p. 57.

17 Ibidem, p. 60.

18 See: G. Lamond, The Coerciveness of Law, "Oxford Journal of Legal Studies" 2000, 20: pp. 39-62.

19 Cf. the nature of state coercion applied against a dissident as described in the political memoir of General Petro Grigorenko (Memoirs, 1982). In 1961, General Petro Grigorenko started to openly criticize what he considered the excesses of the Khrushchev regime.:151 He maintained that the special privileges of the political elite did not comply with the principles laid down by Lenin, an approach and attitude characteristic of Osadchy and other Ukrainian dissidents. Grigorenko formed 
Coercion is deemed present when the coercing agent, in this case, the security agents of the Taiwanese and Ukrainian states, effectively compel individual political prisoners to change their attitude/behavior in accord with authoritarian dictates imposed on them. Several of the particular issues of interest include the writing itself of the prison memoirs and their publication, the nature of the coercive measures and the consequences of the interrogation process, and the laws themselves used to punish and intimidate and sway the behavior of the prisoners both inside the prison and outside.

\section{Coercion in Sweet Potatoes}

Tsai Youde, the author/narrator of Elegy of Sweet Potatoes, was a member of the third generation of Japanese colonialist rule in Taiwan, where education at all levels was conducted in Japanese. The Elegy was originally written in Japanese and published after the abolishment of the Sedition Law in 1991, and subsequently translated into Chinese and English.

The author spent 13 months in cramped and crowded prison cells, the underworld created by the White Terror, the KMT's anti-communist policy that led to the arrest of many innocent victims ${ }^{20}$. His memoir is a record of his encounters and interactions with these denizens, mostly fellow Taiwanese, but also an assortment of Mainlander Communists, each with his own story to tell. While the Martial Law was abolished in July, 1987, the Sedition Law remained in effect until May, 1991, two years after the death of President Chiang Chingkuo (1910-188), son of Chiang Kai-shek (1887-175). Only then did the author feel safe to have his voice heard about Taiwan's gulag.

Tsai Youde managed to limit his time in the penal system to thirteen months without incurring re-arrest. This was a rare feat stemming from Tsai's convic-

a dissident group - The Group for the Struggle to Revive Leninism.:151 Soviet psychiatrists sitting as legally constituted commissions to inquire into his sanity diagnosed him at least three times - in April 1964, August 1969, and November 1969. When arrested, Grigorenko was sent to Moscow's Lubyanka prison, and from there for psychiatric examination to the Serbsky Institute, where the first commission comprised of Snezhnevsky and Lunts, diagnosed him as suffering from a mental disease in the form of a paranoid delusional development of his personality, accompanied by early signs of cerebral arteriosclerosis.

20 Chiang Kai Shek's personal directive stipulated the following: "Do not let one guilty [person] escape even if a hundred are mistakenly killed", T. Tsai, Elegy of ..., p. 418. 
tion of his innocence and the judgment he used in both resisting and yielding to coercive measures. His situation was unique in that he was arrested after he had undergone a rigorous security check prior to his clearance for a year's study in the United States in 1953. He was also fortunate in avoiding coercive interrogative measures (first physical torture, followed by interrogation) that had been employed at the onset of the imposition of the martial law in 1949 and endured by many of his prison mates. He was repeatedly touted as particularly fortunate by his fellow prisoners who had been sentenced to much longer terms, had been mercilessly tortured, some of them awaiting execution.

One of the particularly nefarious measures employed by the Taiwanese security forces in interrogating prisoners was the Self-Renewal Policy. This policy, introduced in May, 1950, rewarded prisoners who denounced others by shortening their prison terms. Such denunciations - driven by self-interest led to the arrest of others, up to thirty in one case, many of whom were essentially victims of their own kindheartedness. Upon arrest, they were subsequently found guilty of aiding and abetting an enemy of the state. Moreover, the reward system allotted to secret police agents after a "successful" sentencing, regardless of the actual guilt of the individual, served to create a system that encouraged false arrests and blatant incrimination.

Youde himself was falsely denounced by Chang Yukun, a childhood friend from the town of Putzu in Chia-yi Country, in order to postpone his own execution. Yukun's final note written just before his death, expresses shame for himself and his country: he had implicated 16 individuals, only three of whom were found not-guilty; six, including Yukun himself, were sentenced to death. Among the victims were individuals who had helped him escape arrest and who gave him money when he was on the run. Among the victims was Yeh Cheng-sung, son of a wealthy father, described by Tsai as privileged, gentle, intelligent, fair-minded, president of the Collegiate Friendship Association, one of the countless Taiwanese elite executed by the firing squad ${ }^{21}$.

Youde was successful in resisting the coercive tactics of the military police during his initial interrogation. His ability to maintain a clear head after four days of intensive questioning by teams of interrogators put him in good stead and made his case exceptional. After his written statement was deemed

21 Ibid, p. 411. 
a betrayal of the interrogators' good will for his failure to admit to reading forbidden books (pro-communist material banned after the fact), Youde was subjected to a session of fatigue interrogation that seemed endless. Forced to remain in a confined room with no access to sunlight, he measured time by the growth of his whiskers: four days of non-stop interrogation were conducted by eight interrogators in turn (68). A member of the Communist Party was subject to arrest under Article 2.1 of the Law of Sedition; those found guilty were likely executed. In Youde's case, reading banned books was proscribed under Article 9 "Receiving Bandit Propaganda Material”. Youde, if found guilty, would have faced a ten-year sentence ${ }^{22}$. A widespread sympathy for communism among students and intellectuals, including Youde himself, was induced by the Taiwanese people's increasing disenchantment with the KMT rule in the late $1940 \mathrm{~s}^{23}$.

The investigation reached an impasse, one of four military trials that Youde underwent until a not-guilty verdict was reached. He was eventually sent to Taipei for a higher-level interrogation. His tenacity in holding out gained him the respect of General $\mathrm{Hu}$, one of his interrogators, and prevented the automatic rubber-stamping of a guilty verdict.

Youde paints a sorrowful picture of a fellow political prisoner, who was a victim of physical coercion. Ghostly and emaciated, he shows up at night in the neighboring prison cell after being interrogated (i.e., tortured) during the day-Zhuang Shui-ching. Two others, acquaintances of Zhuang's who are implicated during his interrogation, are picked up. Zhuang comes face to face in prison with the two men he has denounced, a punishment Youde deems that is worse than torture. The mental anguish of guilt, he declares, is just as painful as physical torture.

In contrast to Yukun and Zhuang, Youde describes a childhood friend and fellow inmate who was capable of standing up to the most intense of coercive measures. Ye Chin-kuei, Youde's grade-school rival for the designation of a model student, is given the moniker "Mosula" for his herculean efforts at

22 Thought control was exercised by both Japanese and Mainland regimes. Reading innocuous volumes, later deemed leftist and banned, was punishable by "thought reform" under Article Nine of the Law on Sedition, a three-year sentence, repeated if deemed necessary.

23 Tsai himself had translated pro-communist plays into Taiwanese and presented them at a student organization, the Blue Cloud Drama Club. 
refusing to denounce his cohorts under "horrendous tortures" at the notorious Green Island Prison. "The ground hardens with rain, the bones strengthen with breakage" - such are Mosula's words after having suffered through the excruciating pain of the breaking of his shin bones during interrogation (384-5).

After his initial round of interrogation Youde was transferred to a warehouse prison of the Military Court to await further interrogation. There he was greeted by a number of inmates including the adolescent $\mathrm{Lu}$, a mere 12-yearold when he was first arrested. Others included a mentally handicapped individual and a former police officer. Youde soon discovered that the prison offered more freedom of expression than the outside, since it was a place where thoughts could be exchanged freely (186) and where a sense of warm camaraderie developed among the unfortunate victims of the Martial Law, all political prisoners arrested under different articles of the Sedition Law. Youde notes the intimate personal relations one develops with inmates he or she spends 24 hours a day with for months at a time.

Prisoners were allowed to take walks in the prison courtyard twice a day, a time when they would sing traditional folk songs, communist songs and at times Japanese popular songs. The common Japanese heritage was an outcome of the prohibition of using the Taiwanese language for most of the $20^{\text {th }}$ century. Such songs as the following one were sung when a fellow inmate was being marched off to his execution, a solemn and personalized sendoff: "To the distant sunset the leaves scatter./ Along the tree-lined road swaying to and fro, / You in a horse-drawn wagon, I see you off./ Parting of yesteryear became forever" (253).

The judges are depicted as men without conscience who view any complication in a case as undesirable and tend to pass such a case to another court to avoid the necessity of admitting a mistake and overturning a case. The innocent victim is caught in a web that takes years to unravel if at all. The system itself discourages anything but the arbitrary judgments of the military court (292-3).

The fourth and final investigation at the Investigation Bureau was a rehashing of old questions about Youde's alleged possession of the proscribed book, "Mao-wen-chi" - the lone deviation from the official record of his deposition. Shortly afterwards he was transferred back to the Military Court Prison after an absence of two months. During that time Youde discovered that two of his 
previous cellmates had been executed and two had been sentenced to long prison terms. Youde at this point learned that his accuser, Yukun, had retracted his denunciation, the primary evidence for Youde's imprisonment. By such means Youde was rewarded for his ability to resist the coercive measures of the state by his persistence in standing up to his investigators, insisting upon his innocence and demanding that his accuser be held accountable for his false denunciation.

Youde, however, refrains from judging his fellow detainees who succumbed to the coercive measures of the state. He loathes condemning those who faced torturers, or sought to extend an imposed deadline for execution. In the case of Yukun, he had denounced Youde in large part because he desperately wanted to see a daughter born during his captivity before his execution.

Youde was informed of his "Not Guilty" verdict at the same time that he learned of the need to undergo "Re-education" - typically a three-year ordeal. He was presented with a document informing him of the reasons he was to undergo re-education: his association with "rebels"; his organization of the Student Friendship Association and the Blue Cloud Drama Club in which rebels (i.e., Communists) were members; his reading of "reactionary literature" including the works of the modern classic, Lu Hsun, and a work on dialectical materialism in Japanese. The reading of such works suggested to the authorities that he harbored "pro-rebel sympathies". The decision imposed on Youde to undergo the mandatory treatment was in accordance with Item 2.1 of Article 8 of the Statutes for the Denunciation and Punishment of Bandit Spies During the Emergency Period (dated April 11, 1955) signed by Fan Chueh Fei, Military Court Prosecutor. Youde learned that he was the $1,478^{\text {th }}$ individual to undergo re-education, the lightest form of sentences handed down to detainees ${ }^{24}$.

Youde, however, was also a victim of the coercive measures of the state. In order to expedite his release from prison Youde found himself in the compromising position of having to betray his principles during the re-education program. One example he provides has to do with the need to pay open homage to President Chiang Kai-shek, the individual he held most responsible for the sufferings of his fellow Taiwanese. As part of his re-education, Youde had the obligation of commenting on the saying "Repaying enmity with virtue" 
at an open discussion session. The saying reflected Chiang's principles as a student of Confucian thought and it was Youde's duty to illustrate the saying with respect to Chiang's own historical role as a leader of the Chinese people. Youde responded with an effective and seemingly sincere anecdote of Chiang's benevolent treatment of the one million Japanese soldiers stationed on Taiwan at the war's end. Chiang's helpfulness in providing transport for their return to the Japanese mainland saved many lives. Their early repatriation contributed greatly to post-war recovery. The gratefulness of the Japanese government toward Chiang was expressed formally at the time and good relations between Taiwan and Japan continue to the present day. Yet Youde saw a large degree of self-interest in Chiang's assistance to the Japanese; a Japanese military presence in Taiwan would pose a potential threat to his rule. Young Taiwanese, on the other hand, were shown no mercy because they too posed a threat to his political well-being. His treatment of the Taiwanese and the terror he imposed on them destroyed their good will. According to Youde, Chiang repaid the nation's benevolence with violent retribution (418). This sentiment, however, remains unexpressed until many years after Chiang's death.

Youde also yielded to coercion in signing a document upon his release to support the regime that had imprisoned him and his countless fellow "sweet potatoes". In signing the following statement he had to make a solemn vow of loyalty: "I, Tsai Youde, swear to believe in the Three People's Principles, to support President Chiang, and, to the best of my ability, shall work for the sacred war against Communism and Russia” (428). The inclusion of Russia serves to underscore "Free China's" status as a Cold-War ally of the United States.

Prior to his release, Youde was once again coerced into accepting a condition against his well with significant ramifications. He was warned by a prison official to make a vow of silence concerning the outrages of the government: "You must not tell people about what you have heard or seen in here...it's equivalent to engaging in activity beneficial to the enemy, punishable according to Article 7 of the Law of Sedition" (429). Youde accepts the need to swear silence to all he has witnessed in the underground world of White Terror and to hold the truth as hostage. Moreover, he is coerced into agreeing to help the government in whichever form is deemed useful. This entails the possibility of serving as a government spy and denouncing others in order to become a "free" man. 
The success of the Chiang regime's policy of terror intimidated the nation, cowed them into subservience and largely prevented victims from openly expressing criticism of the government and maintaining a decades-long silence of the horrors of White Terror. Likewise, the document political prisoners were forced to sign upon their release to refrain from telling others of the nature of the prison system and their experiences and victimization while in it, meant that Tsai's memoir was only written in the early 1990s when the Sedition Law was formally rescinded. Only then was the recovery of historical memory prioritized. Martial law was abolished in July, 1987, the Sedition Law remained in effect until May, 1991, three years after the death of Chiang Ching-kuo. Only then did the author feel safe to speak and write about Taiwan's gulag.

\section{Coercion in Cataract}

Mykhajlo Osadchy was a creative individual with a strong intellectual bent, a poet whose rich expressive lyrics written in prison gave voice to both personal and collective suffering. As a member of the Ukrainian resistance, his writings, including Cataract as well as a collection of verse, Quos Ego, were published as tamizdat, that is, they were published abroad in West Germany by the local Ukrainian émigré community. Both the lyrics and the memoir express the personal suffering of a husband, father, artist, and camaraderie of the inmates in the Mordvinian labor camp who, coming from many Soviet republics, formed an underground microcosm of the Soviet Union. Cataract is part memoir, part essay, part inspired lyricism, as Osadchy gives himself over to moments of darkness and near despair. Yet the creative effort itself is a form of catharsis which ultimately serves to strengthen his inner resolve and to forge a more intimate relationship with his literary forbears who also suffered in Russian and Soviet prisons. It serves likewise to strengthen his ability to resist the regime's coercive efforts to submit to its will and sign a formal confession. Like his Taiwanese counterpart, he was separated from his family members, from wife and child, yet like Tsai, Osadchy was able to draw upon the collective strength of the community of political prisoners as well as his own expressive resources of language to maintain inner freedom, to steadfastly 
affirm his political and artistic convictions and to create a collective voice of the community of political prisoners.

One distinction between the situations of the two writers is that Osadchy was a member of a community of dissidents arrested in one fell swoop, whereas Tsai's arrest was isolated and belated, having taken place after the most intense period of arrests in the late 1940s and early 1950s. Tsai, consequently, had to largely fend for himself, whereas the resistance of Ukrainian dissidents was strengthened by their fellowship and common purpose of promoting Ukrainian cultural and political autonomy. Two important contemporaries of Osadchy who were urgently concerned about the repressive measures taking place in Ukraine in 1965 and the imprisonment of Ukrainian dissidents, and who saw themselves as loyal communists, are described in detail in Cataract.

Vyacheslav Chornovil (1937-1999) and Ivan Dzyuba (1931-2018) shared a common fate with Osadchy. Chornovil was a reporter on the 1965 arrests and open trials of the dissidents in Lviv, and, as it turned out, a central figure in the Ukrainian resistance. A member of the Communist Party - as were Osadchy and Dzyuba - he appealed to Soviet law to prevent the KGB from persecuting Soviet citizens for their beliefs. In challenging the regime, he compiled a selection of prison camp literature, the so-called Chornovil Papers, to which he gave the explosive title of The Misfortune of Being Intelligent, a title all too familiar to literate Russians that concerns the plight of the intellectual in a repressive regime ${ }^{25}$. Subtitled "Portraits of Twenty Criminals", it became "an exposé of the arbitrary, illegal and cynical manipulation of the judicial system by the Soviet authorities"26. Chornovil himself was sentenced in November 1967 to three years of imprisonment and rearrested for his refractory insistence that Soviet laws be followed.

Dzyuba, a literary critic and essayist, also appealed to the authorities to put a halt to the arrests and release the nation's young elite. In his highly influential essay, "Internationalism or Russification?" (1968), he described in detail

25 The title refers to Aleksandr Griboedov's famous early $19^{\text {th }}$-century play, The Misfortune of Being Intelligent (Gore ot uma) which authorities in the Russia of Nicholas I found too threatening to be allowed to publish. Written in 1825, it was not published until after the death of the author, in a heavily censored version in 1833 and in an academic version by the scholar N. K. Piksanov in 1913.

26 O. Subtelny, Ukraine: A History, p. 517. 
the broad swathe of Russian cultural intimidation imposed on non-Russian peoples within the Empire. Dzyuba championed civil liberties, national rights, and the freedom to discuss national affairs; he was an outspoken proponent of freedom of choice, of national self-knowledge, of the right to open discussion and disagreement. He, like the Sixtiers as a whole, was concerned by the yawning gap between Soviet theory and reality. He was charged with anti-Soviet activity in 1972, sentenced to five year' prison and five years' exile.

A third important contemporary of Osadchy featured in his memoir is Valentyn Moroz, an integral nationalist, who was hostile to the Soviet system - unlike most Ukrainian dissidents who were essentially reformists opposed to revolution or separation. He voiced opposition to the influx of Russians into Ukraine and their unfair advantages in competing for good jobs, seeing it as yet another manifestation of the long-standing confrontation between Ukrainian autonomy and the unhappy fate of its intelligentsia and the Russian imperial state and its stifling bureaucracy. His "Report from the Beria Reserve" (1970) was written after his arrest - also for anti-Soviet agitation. The report was a strong attack on Soviet officialdom, including its security agencies for degrading and destroying the lives of citizens and entire peoples whom they should be serving and protecting. It opposed the regime's nationalities policy, russification and cultural genocide, and denounced the lawless brutality of the complex of camps in Mordovia ${ }^{27}$. His work, as Osadchy's Cataract, was smuggled to the West and published through the assistance of Ukrainian emigres.

The act of writing prison memoirs is an act of defiance directed at the coercive forces implemented by the authorities to intimidate and silence the individual and like-minded comrades. It is an attempt to portray and convey to outside readers the repressive nature of the underground world to which the author/victim has been transported and where he experiences and relates firsthand life in all its cruelty "in the belly of the beast". Osadchy's prison essay is a powerful form of resistance since it is a form of protest against actual conditions with the hope of rectifying them. It is also an act of solidarity with a community of support both within and outside the prison, and a source of 
strength for the individual inmate to persist in the struggle against coercive acts of the authorities ${ }^{28}$.

Osadchy paid a stiff price for writing his memoir and for its publication abroad (1971). He was re-arrested in 1972 and sentenced to a much longer prison term and exile totaling ten years (compared to the two-year term of his first incarceration). Yet, the writing and its circulation among fellow dissidents, even though Osadchy did not intend to publish it abroad, represent an unwavering act of resistance to the authorities whose actions he considers as contrary to Soviet law and human rights, and an unwillingness to be cowed into submission.

The younger generation of Ukrainian dissidents of the 1960s was armed with significant knowledge of the Soviet Constitution, of Lenin's views on nationalism ${ }^{29}$ and the law in general. They were opposed by a police and the judicial system, whose mindset had been forged under Stalinism, rendering its members fearful of criticism, crippled with inflexible minds and characterized by a wholesale lack of curiosity of the new currents that had enlivened the minds of Ukraine's youthful intellectuals. Their main raison d'etre was to preserve their grip on power with all the means the Stalinist state provided them.

Osadchy demonstrates his resistance to coercive measures perpetrated by the state during his trial which began at Lviv Provincial Court on April 16, 1966. There he was charged under Article 62 of the Ukrainian Criminal Code with perpetrating anti-Soviet agitation and propaganda, and circulating manuscript articles and Ukrainian books published abroad. His response was to condemn the regime for not upholding the tenets of Marxism-Leninism. His defense lawyer, moreover, demanded public prosecution of the trial with respect to Article 20 of the Code of Criminal Procedure, in stark contrast with the closed-door judgments passed in the dark halls of the Military Court of Taiwan. Chornovil himself refused to give evidence at Osadchy's trial because it was not open to the public. Open trials were stipulated by the Soviet law ${ }^{30}$.

28 Ibid.

29 See G. S. N. Luckyi, Literary Politics in the Soviet Ukraine 1917-134, Durham 1990, pp. 5-22.

30 M. Carynnyk, p. xviii. 
Chornovil, in turn, was charged for violating Article 179 of the Ukrainian Criminal Code for refusing to give evidence without grave reasons: "I regarded a violation of socialist legality (public trials) as a sufficiently grave reason to justify my decision" (164). He also attacked the high-handed measures of the court to pass down judgment without explaining why. His relentless insistence in standing up for the truth in the crucible of the courtroom convinced the Supreme Court to withdraw most of the charges against Osadchy and declared no formal crime was committed in his actions. "Is reading literature a crime?" (170 - letter to Chornovil) The answer to that question is reflected in the fates of both Osadchy and Tsai.

The trial revealed the integrity of a young member of the intelligentsia whose native intelligence, curiosity and a concern for social justice, a concern for "the purity and irreproachability of the Soviet way", were distorted by the criminal justice system into anti-Soviet activity, a view that would remain a tangible threat to the generation until the demise of the Soviet Union itself (161). For Osadchy, an important source of fortitude to remain true to himself came from the words and spirit of Ukrainian writers of the past, including Ivan Franko (1856-116), a leading figure in raising Ukrainian national consciousness in the decades prior to World War I. In spite of all the trials and tribulations, fate brought his way, as he declares "I shall be led by, my guiding star will be, my desire to be of service to my people. Ivan Franko wrote this once, and I shall repeat it to my dying day" (171).

In June 1966, Osadchy was dispatched to a camp in Dubrovlag, the largest labor-camp complex in the Soviet Union, outside the village of Yavas in Mordovia, 350 miles southeast of Moscow. In the 1960s the camp had a population of 30,000 prisoners. Osadchy was assigned to Camp No. 11 together with 4,000 other political prisoners and assigned to work as a joiner to pay for food and clothing. Upon his release in March 1968, Osadchy was compelled to testify at the trial of Vyacheslav Chornovil. Once again he demonstrated his resistance to coercive state measures, where he spoke in favor of the defendant, in spite of the accused having damning testimony. Displeased with his performance, the authorities refused to grant him a residence permit in Lviv, which made it impossible to lead a normal life and to obtain work in his professional field.

The second part of the memoir, a description of life in prison, is given the ironic title "City of the Sun" (1602). Tomasso Campanella's original work of 
that title is a vision of a peaceful unified world in a dialog form inspired by Plato's Republic. "City of the Sun" was a work written in prison after Campanella had been denounced to the Inquisition, betrayed by his comrades, and tortured on the rack, having spent a total of twenty-seven years in prison. Yet, even in prison he was able to influence the intellectual life of the times, setting a powerful example for imprisoned Ukrainian intellectuals ${ }^{31}$.

For Osadchy, prison life, in part, reduced the language to vulgar phrases, brought the cacophony of hell, the sense of being obliterated, of being buried alive. The state of incarceration forced a dark view of life: "When you want the day to begin in the evening so you can foresee your own dying so that life would be easier to bear (Thoreau turned upside down)." Osadchy's perspective is the antithesis of Thoreau's paean to morning in Chapter Two of Walden (1855). The American author would expand the limits of the morning hours - the most vital and alive moments of the day - into an unceasing poetic living; Osadchy's world, bereft of sunlight, is turned into life-despairing darkness (6).

Osadchy's nightmarish vision of the "crypt" appears as a coffin for Ukrainians, an end to the dream of a just society. In his surrealist graveyard, a dead man rises from his coffin, and taking a deep breath, throws himself into a rage against the gravedigger: what has driven him out: who is to blame? The dead man's own thought, a crack in the lid and the play of sunlight. The prisoner in the cell is beckoned to the wall by a bell tower with no bells. The new model of the world yet lies in wait. A horse with St. George the Conqueror is mounted astride (140). In spite of his dark despair and the physical and emotional sufferings he is forced to undergo, the spirit remains resistant. The resurrection of the spirit within the walls of a prison is a prelude to social and political transformation.

Osadchy's real despair is matched and overcome by the willful resistance to persevere in his endeavor to be true to himself morally and artistically, and to preserve his dignity as a human being. His faith is reinforced by the camaraderie of his fellow inmates, writers of conscience from all parts of the Soviet Union. The camp slogan is bracing: TO FREEDOM WITH A CLEAR CONSCIENCE! It is the terrible freedom of the political prisoner to resist the rewards for choosing conformity, for relinquishing his will; it is the freedom

31 G. Ernst, Tommasso Campanella, [in:] The Stanford Encyclopedia of Philosophy, 2010. 
of self-denial: "the freedom to choose to eat gruel, the freedom not to accept a parcel from home since it comes at a price" (146).

His fate is compared by his English editor Carrynyk to that of Shakespeare's Caliban: one who is reduced by the ravages of the system to a savage and deformed slave, yet one who dares to dream of a better tomorrow. It is, after all, in prison that he encounters the wisdom of the east in the form of the poems of the Turkmen Makhtum-kuli (1724-1807), the experience of being embraced by wisdom, of gaining an insight into the nature of things, of being endowed with a feeling of mastery that is both exalting and ennobling. The political prisoner finds consolation in Article 17 of the Soviet Constitution: "every republic has the right to secede." Life is nothing if the nation is in chains; those who are imprisoned seek out minds that stand for something.

\section{Concluding Remarks}

\author{
"The price of anything is the \\ amount of life you pay for it."
}

Thoreau

Tsai left the Hsin-tien prison behind after thirteen months, a period he compared to five years of "normal life" for his intense confrontation with the system, and even more by his encounter with the human condition of victimhood in so many variations in the Taiwanese underworld. The man who enters a prison is not the same as the man who leaves it. His wife who was given a ten-minute interview with Tsai during his detention noted that he looked "kinder and gentler". Yet the stories of his fellow Sweet Potatoes would wait forty years to be written down and published. The coercive measures of the authoritarian regime were largely effective in imposing a curtain over the deeds done during the period of White Terror, delaying Tsai's version of the truth by over forty years.

For Osadchy, prison meant that his health was undermined and his future prospects remained uncertain. He was only able to return to a life of normalcy in 1990 when he returned to the University of Lviv, twenty-five years after his first arrest. The penning of his memoir, an act of resistance, was inspiring to 
his fellow writers in their own creative efforts as was the recognition of his status as a prisoner of conscience by Amnesty International. But back home it meant a return to prison for him and subjection to KGB efforts to obliterate his existence. Two years after the publication of Cataract abroad, his name was recorded on a KGB blacklist of writers who had become personae non grata, those who may not be mentioned in the Soviet press and remain invisible to the public at large.

Both Tsai and Osadchy, representative writers of Taiwan and Ukraine, respectively, came to understand that those unwilling or unable to resist the coerciveness of an authoritarian system suffered more profoundly than those who had the moral courage to stand their ground. They realized that those who signed confessions endorsing the status quo and those who made secret denunciations suffer a terrible and lasting punishment. They are haunted by their deeds and condemned by the weight of human justice. Both countries remain precariously placed by history and geography. The lessons of the past should be studied well and mastered to be better prepared for any and all eventualities.

\section{Bibliography}

Alexeyeva L., Goldberg P., The Thaw Generation: Coming of Age in the Post-Stalin era. Pittsburgh: University of Pittsburgh Press, 1990.

Bedford O., Kwang-Kuo H., Taiwanese Identity and Democracy: The Social Psychology of Taiwan's 2004 Elections, London: Palgrave, 2006.

Campanella T., The City of the Sun, Project Gutenberg.

Chronicle of Current Events for Human Rights and Freedom of Expression in the USSR “Moroz, Valentyn" :https://chronicleofcurrentevents.net/2014/04/28/17-2the-trial-of-valentin-moroz/

"Coercion". Stanford Encyclopedia of Philosophy. Revised version. 2011.

Dzyuby I., Internationalization or Russification? (London, 1968, and "Motherland" magazine (“Вітчизна"), 1990, №. 5-7.

Ernst G., Tommasso Campanella, [in:] The Stanford Encyclopedia of Philosophy, 2010.

Hobbes Th., Leviathan, Pacific Publishing Studio, 2011. 
Hornsby R., Protest, Reform and Repression in Khrushchev's Soviet Union, Cambridge: Cambridge University Press, 2013.

Kelsen H., The Pure Theory of Law, Max Knight (trans.), Los Angeles: University of California Press, 1967.

Lamond G., The Coerciveness of Law, "Oxford Journal of Legal Studies" 2000, 20: 39-62.

Locke J., Two Treatises of Government, [in:] The Works of John Locke, A New Edition, Corrected, Vol. V, London, 1823.

Lucas J. R., The Principles of Politics, Oxford: Clarendon Press, 1966.

Luckyi G. S.N., Literary Politics in the Soviet Ukraine 1917-1934, revised and updated edition. Durham, NC: Duke University Press, 1990.

Luckyi G. S.N., ed. Shevchenko and the critics, 1861-1880, Toronto: University of Toronto Press, 1980.

Luckyi G. S.N., The Ukrainian Literary Scene Today, "Slavic Review" 1972, Vol. 31, No. 4 (Dec., 1972) 863-869.

Nozick R., Coercion, [in:] Philosophy, Science, and Method: Essays in Honor of Ernest Nagel, Sidney Morgenbesser, Patrick Suppes, and Morton White, New York: St. Martin's Press, 1969, p. 440-472.

Osadchy M., Cataract, translated, edited and annotated by Marco Carynnyk. New York: Suchasnist, 1976.

Osadchy M., Quos Ego, Kateryna Hrobac, ed. New York, Suchasnist, 1979.

Pazuniak N., Review of Quos Ego in World Literature Today 55 1, 1981.

Smal-Stotsky S., 'O, Why have you darkened', [in:] Luckyi, op. cit., 240-249.

Steele J., "Who started it?" (Review of The Cold War: A World History by Odd Arne Westad), “London Review of Books" 2018, January 25, p. 23-25.

Subtelny O., Ukraine: A History, Fourth Edition, Toronto: University of Toronto Press, 2009.

Sworzen M., Opis Ukrainy Gog: Latopis A.D. 2007, Warszawa: Biblioteki Więzi, 2011.

Taylor J., The Generalissimo's Son: Chiang Ching-kuo and the Revolutions in China and Taiwan, Cambridge: Harvard University Press, 2000.

Tromly B., An Unlikely National Revival: Soviet Higher learning and the Ukrainian "Sixtiers", 1953-1965, “The Russian Review" 2009, Vol. 68, No. 4, p. 607-622.

Tsai T., Elegy of Sweet Potatoes: Stories of Taiwan's White Terror, translated by G. Hatch, Taipei: Taiwan Publishing Co., 1995. 